\title{
South American lake paleo-records across the Pampean Region
}

Felipe García-Rodríguez', E. Piovano², L. del Puerto' ${ }^{1}$, H. Inda ${ }^{1}$, S. Stutz ${ }^{3}$, R. Bracco ${ }^{1}$, D. Panario ${ }^{1}$, F. Córdoba ${ }^{2}$, F. Sylvestre ${ }^{4}$ and D. Ariztegui ${ }^{5}$

'Oceanology Section, Faculty of Science, University of the Republic, Montevideo, Uruguay; felipe.garciarodriguez@gmail.com

${ }^{2}$ CICTERRA-CONICET, National University of Cordoba, Argentina; ${ }^{3}$ Faculty of Exact and Natural Sciences, National University of Mar Del Plata, Argentina; ${ }^{4}$ Aix-Marseille University, IRD, CNRS, CEREGE, Aix-en-Provence, France; ${ }^{5}$ Section of Earth and Environmental Sciences, University of Geneva, Switzerland.

\section{Paleolimnological studies of shallow lakes in the Pampean plains of South America provide detailed information on their response to both climate and anthropogenically-induced changes through time.}

\section{Study area and motivation}

The lowland area east of the Andes stretches from Colombia and Venezuela in the North to the Argentinean Pampas in the South (approx. $40^{\circ} \mathrm{S}$ ), and is a unique environment due to the development of a monsoon-like atmospheric pressure system (Vera et al., 2006). A mild climate dominates the more than $750,000 \mathrm{~km}^{2}$ region, with a mean annual precipitation ranging between 600 and $1200 \mathrm{~mm}$, making the soils appropriate for agriculture, cattle/sheep grazing and associated farming activities. The southernmost portion of this vast region is characterized by the fertile lowlands of the so-called "Pampas", including central to eastern Argentina, most of Uruguay, and the Rio Grande do Sul state in Brazil (Fig. 1a). The prevailing flat geomorphology of the area promotes the occurrence of shallow lakes that provide excellent paleoenvironmental archives. Recent investigations in South America have highlighted the advantage of studying past climate variability from a regional perspective (e.g., LOTRED-SA PAGES Working Group). This research was triggered to a large extent by early efforts led by the PAGES PEP-I initiative that resulted in a substantial increase of limnogeological studies in South America.

\section{Calibrating the sedimentary} record of recent climate changes

The $20^{\text {th }}$ century in the Argentinean Pampa has been characterized by pronounced hydrological variability as evidenced by distinct lake level fluctuations, varying river discharges, and an extension of flooded lowlands (Fig. 1a and b). Piovano et al. (2002) have shown that the most recent sediments of Laguna Mar Chiquita (Fig. 1a) provide a unique sedimentological and geochemical record of these environmental changes. A stable isotopic model was generated, calibrated against instrumental data and further applied to older sediments (Piovano et al., 2004). This pioneer work using a limnogeological approach resulted in the development of the ongoing PALEO-PAMPAS initiative that aims to identify the role of the sub-

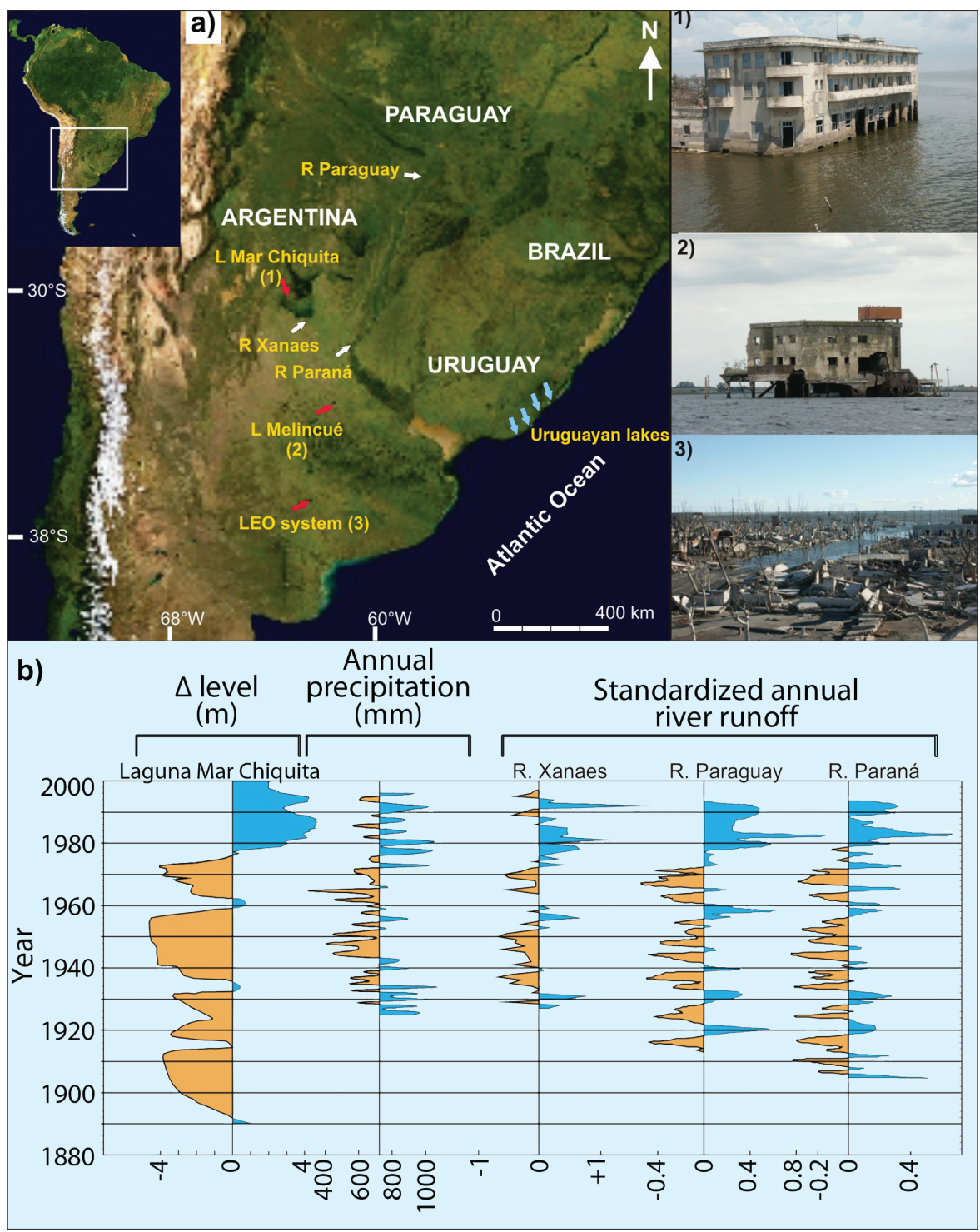

Figure 1: a) Satellite image of study area (composite image created by NASA, public domain). White arrows indicate location of Xanaes River, Paraguay River and Paraná River gauging stations used in graphs of (b), red arrows indicate location of Pampas lakes (Mar Chiquita Lagoon, Melincué Lagoon and Lagunas Encadenadas del Oeste de Buenos Aires (LEO)), and blue arrows indicate location of Uruguayan lakes. Photographs on right illustrate the consequences of water-level increase: 1) Mar Chiquita Lagoon, 2) Melincué Lagoon, 3) Epecuén Lagoon in the LEO system. b) Comparison of instrumental lake level for Mar Chiquita Lagoon with an instrumental precipitation record and river runoff data. A lake level of 0 indicates an intermediate level that matches the AD 1977 shoreline (66.5 $\mathrm{m}$ as I). Positive values represent highstands (blue areas), and negative values indicate lowstands (brown areas). Annual precipitation in the Mar Chiquita lagoon basin covers AD 1925-96 interval. Values above average are in blue and below average in brown. Standardized runoff of Xanaes (within the Mar Chiquita lagoon basin), Paraguay, and Paraná Rivers with discharges above and below the mean annual runoff indicated in blue and brown, respectively (for further details see Piovano et al., 2004).

tropical air masses during atmospheric circulation shifts beyond historical times (http://www.cicterra-conicet.gov.ar/english_areas-limno-programa.htm). As for the Laguna Mar Chiquita record, the main goal of this research is to now extend the reconstruction of past hydrological vari- ability along a latitudinal transect in central Argentina (Fig. 1a). This reconstruction will be accomplished using sedimentological, geochemical and biological proxies in lacustrine sequences.

Since the 1970s, hydroclimatic change has also been occurring at a sub-continen- 
tal scale, covering the vast and productive region of southeastern South America (SESA) between $22^{\circ} \mathrm{S}$ and $40^{\circ} \mathrm{S}$. Thus, it affects Uruguay, Paraguay, and subtropical regions of Argentina and Brazil. The close correspondence between the $20^{\text {th }}$ century hydrological variability in both Pampean lakes and large-scale fluvial systems (e.g., Río Paraná; Río Paraguay; Fig. 1) highlights the significance of these Pampean lacustrine archives for reconstructing the past activity of the monsoonal system at a subcontinental scale.

Recent investigations in lake basins in Uruguay $\left(\sim 34^{\circ} \mathrm{S}, 54^{\circ} \mathrm{W}\right.$; Fig. 1) have shown a clear nutrient enrichment during the past 70 years associated with a welldocumented increase in human impact in the region (García-Rodríguez et al., 2002; 2004; Inda et al., 2008). Present-day nutrient levels of anthropogenically-disturbed lakes indicate highly eutrophic conditions. Although, these conditions are also affected by other factors, such as basin morphometry, lake-use, catchment geology and climate, it seems clear that the most intense eutrophication is related to the human impact of the past century (Fig. 2). Paleolimnological results indicate that, over long timescales, similar trophic states to those observed at present existed during the Holocene, due to climate and sea level variations (García-Rodríguez et al., 2004; del Puerto et al., 2006).

\section{Holocene variability}

The methods used on the most recent sediments of Laguna Mar Chiquita have now been applied down core on the older sediments. Results from these analyses show substantial regional hydrological variability since Late Glacial times and throughout the Holocene (Piovano et al., 2009). In addition, dominant dry conditions were observed during cold phases, such as those occurring during the midHolocene or the Little Ice Age (LIA), whereas wet conditions prevailed during warm climatic phases such as the Medieval Climatic Anomaly (MCA) or the late $20^{\text {th }}$ century. Paleohydrological reconstructions suggest that the magnitude of the MCA wet phase was comparable to that of the present-day conditions. Thus, the results emerging from the PALEO-PAMPAS initiative have: a) lengthened the time-frame of existing instrumental datasets of climate variability; b) reconstructed past hydrological variability within a broad region of SESA including new sites in the Río de la Plata/Paraná Basin; c) resolved this variability at decadal timescale for the past 200-300 years and during older time windows; and d) analyzed past hydroclimatic

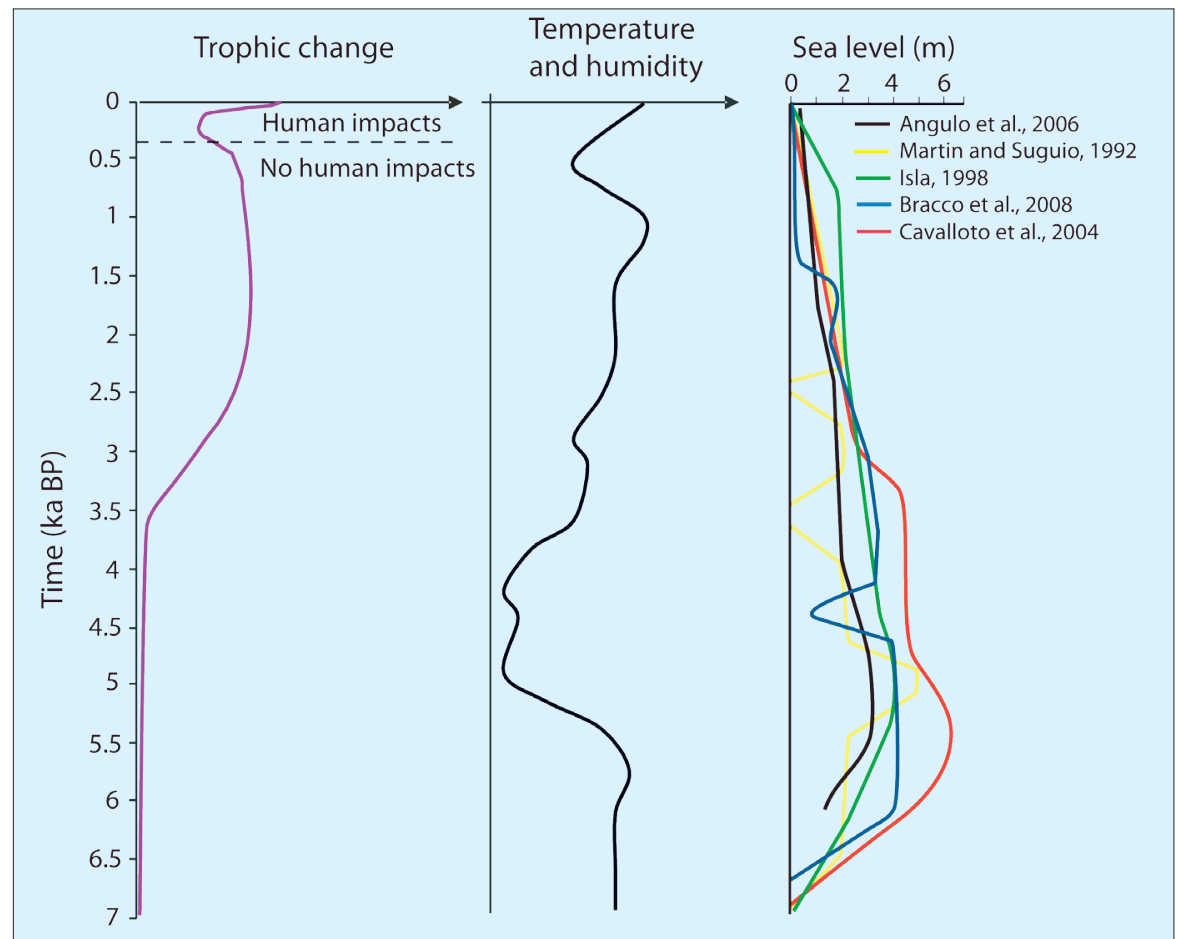

Figure 2: Conceptual paleolimnological model displaying the relationship between trophic development of Uruguayan lakes (purple line), climate change in the region (black line) and Holocene sea-level curves (colored lines) observed in Uruguayan lakes. Temperature and humidity curves were reconstructed from opal phytolith data (Bracco et al., 2005; Inda et al., 2006; del Puerto et al., 2006; 2008; 2009). Sea level curves reconstructed from stratigraphical and topographical data.

scenarios at times of either little or no anthropogenic impact.

Similarly, research in Uruguayan lakes (Fig. 1) has focused on Holocene paleolimnological variations of coastal lacustrine systems linked to changes in sea level, as well as in climate and anthropogenic impact. Diatoms, chrysophyte cysts, opal phytoliths, and palynomorphs have been used as biological proxies for changes in lake trophic status, salinity, and climate. Diatom taxonomy studies of both recent and fossil taxa in Uruguay led to the description of 101 new diatom species and one new genus (Metzeltin et al., 2005; Metzeltin and García-Rodríguez, 2003). Although the new diatom species have not yet been calibrated versus environmental data, the ecological/trophic preferences have been documented. Trophic state and salinity changes were also inferred after adapting the cyst to diatom ratio findings (Smol, 1985) to temperate/subtropical lagoons influenced by sea-level changes (García-Rodríguez, 2006). The reliability of the ratio to infer changes in paleosalinities was successfully tested in other Uruguayan lakes by Inda (2009). In addition to biological indicators, geochemical proxies have been used to infer nutrients and lake productivity (Bracco et al., 2005; del Puerto et al., 2006; García-Rodríguez, 2006). These results demonstrated that the Holocene eutrophication of coastal lakes was controlled by sea-level variations and climate change. Higher trophic states were observed during marine regression events and climatic warming, while transgression and climate cooling led to lower trophic states (Fig. 2).

Thus, both modern limnological and paleolimnological data should be combined when designing the best possible management strategies, with paleolimnological data being especially useful for identifying the different causes and effects of eutrophication. Specific research efforts are currently being undertaken to compile an opal phytolith atlas as a taxonomic and ecological basis for both paleoclimatic and paleobotanical investigations. Concomitantly, opal phytolith assemblages from cattle enclosure sites are being studied to obtain quantitative data in view of distinguishing grazing and natural impacts on their distribution, thereby providing more realistic climate reconstructions. The combined use of opal phytoliths and pollen is thus an ideal approach to achieve more complete and reliable reconstructions of both climate and vegetation change. In the Buenos Aires province (Argentina), intensive fieldwork is being undertaken in several coastal lakes in view of multi-proxy reconstructions.

\section{Conclusions and outlook}

Although paleolimnological studies in the Argentinean and Uruguayan Pampas are relatively incipient, they have already provided critical information on the regional response of aquatic systems to climate variability. The combined results of these research initiatives highlight the key role 
of the subtropical region of South America (i.e., the transition between the tropics and the extra tropics) in deciphering the forcing factors of past changes in atmospheric circulation. Both Argentinean and Uruguayan Holocene paleolimnological records indicate similar paleoclimatic trends, i.e. dominant dry conditions were observed during cold phases, whereas wet conditions prevailed during warm climatic phases. To our knowledge, this is the first attempt to integrate paleoclimatic data for the whole Pampean region. In addition, our results underscore the need to reinforce paleoclimate research at mid-latitudes in South America, in an attempt to fully appreciate natural climate variability beyond the instrumental record, as well as to design new strategies for the sustainable development of ecosystems and natural resources.

\section{Acknowledgements}

PEDECIBA, SNI-ANII and CSIC-Program "Contratación de investigadores provenientes del exterior" (Uruguay) are thanked for financial support. Part of this study was supported by Argentina through funding of CONICET (PIP 5947; PIP 112-200801-00808), FONCYT (PICT No 25594 and PICT 2006-00625) and SECYT (UNC).

\section{References}

Bracco, R., Inda, H., del Puerto, L., Castiñeira, C, Sprechmann, P. and García-Rodríguez, F., 2005: Relationships between Holocene sea level variation, trophic development and climate change in Negra Lagoon, southern Uruguay, Journal of Paleolimnology, 33: $252-262$ del Puerto, L, García-Rodríguez, F., Inda H., Bracco, R., Castiñeira, C., J.B. and Adams, J.B., 2006: Paleolimnological evidence of Holocene paleoclimatic changes in Lake Blanca, southern Uruguay, Journal of Paleolimnology, 36: 151-163.

García-Rodríguez, F., 2006: Inferring paleosalinity changes using the chrysophyte cyst to diatom ratio in coastal shallow temperate/ subtropical lagoons influenced by sea level changes, Journal of Paleolimnology, 36, 165-173.

Piovano, E., Ariztegui, D., Bernasconi, S.M. and McKenzie, J.A., 2004 Stable isotopic record of hydrological changes in subtropical Laguna Mar Chiquita (Argentina) over the last 230 years, The Holocene, 14(4): 525-535.

Piovano, E.L., Ariztegui, D., Córdoba, F., Cioccale, M. and Sylvestre, F., 2009: Hydrological variability in South America below the Tropic of Capricorn (Pampas and Patagonia, Argentina) during the last 13.0 In: Vimeux, F. et al., (Eds.), Past climate variability in South America and Surrounding regions: From the Last Glacial Maximum to the Holocene, Developments in Paleoenvironmental Research Series (DPER), pp 323-351,

For full references please consult:

www.pages-igbp.org/products/newsletters/ref2009_3.html

\title{
Results of recent sediment drilling activities in deep
}

\section{crater lakes}

\author{
Reinhard Pienitz' ${ }^{1}$, M. Melless and B. Zolitschka ${ }^{3}$ \\ 'Aquatic Paleoecology Laboratory, Centre for Northern Studies, Université Laval, Quebec City, Canada; reinhard.pienitz@cen.ulaval.ca \\ 2Institute of Geology and Mineralogy, University of Cologne, Germany; mmelles@uni-koeln.de \\ 3GEOPOLAR, Institute of Geography, University of Bremen, Germany; zoli@uni-bremen.de
}

\section{Long terrestrial sediment records from deep crater lakes reveal precious paleoclimate archives.}

Since the beginning of concerted efforts to extract long continental paleoclimate archives from lacustrine sediment records (see Leroy and Williams, 1996; Ariztegui, 1999), the terrestrial paleoclimate community has made substantial progress in providing precious paleoclimatic information from a number of sites in both hemispheres. Here we report on the latest achievements and progress made in three of these projects that concern large and deep crater lakes.

\section{Laguna Potrok Aike}

The Potrok Aike Maar Lake Sediment Archive Drilling Project (PASADO) is a deep lake drilling project sponsored by the International Continental Scientific Drilling Program (ICDP), as well as the German and Swiss National Science Foundations, Natural Sciences and Engineering Research Council of Canada, the Swedish Vetenskapsradet, and the University of Bremen (Haberzettl et al., 2007). Laguna Potrok Aike $\left(51^{\circ} 59.0^{\prime} \mathrm{S}, 70^{\circ} 21.0^{\prime} \mathrm{W}\right.$; $113 \mathrm{~m}$ asl, diameter 3.5 km, water depth 100 m; Fig. 1a) is a late Quaternary volcanic crater lake in southern Patagonia (Argentina). From September through November 2008, sediment cores were retrieved by an international team from all funding countries and the United States using the GLAD800 drill rig. A total of $513 \mathrm{~m}$ of sediments were recovered from two sites in seven holes and resulted in a composite sediment length of $107 \mathrm{~m}$, potentially representing a lacustrine archive of southern hemispheric environmental change of the past ca. 80 ka. Core sections and sediments are now stored and archived in the GEOPOLAR lake core repository at the University of Bremen. Various non-destructive analyses (multi-sensor core logger, digital photography and radiography, reflectance photospectrometry, magnetic susceptibility, XRF scanning) are almost complete while sub-sampling of the cores is underway for analyses of biotic and abiotic proxies (pollen, diatoms, chironomids, stable isotopes, rock- and paleomagnetics, geochemistry, grain size, mineralogy, pigments, organic petrology, microbial activity). Moreover, radiometric and luminescence dating techniques and tephrochronology will be applied to assure the best possible time control. The analysis of this unique Southern Hemisphere sediment record will provide insights into lacustrine ecosystem response to climate forcing since the onset of the last glacial, and will allow correlation of this record with marine and Antarctic counterparts to detect landocean-cryosphere-atmosphere interactions. Information on the latest progress of this research project can be found at http://www.pasado.uni-bremen.de or http://www.icdp-online.org/contenido/ icdp/front_content.php?idcat $=722$, or by contacting Bernd Zolitschka.

\section{Pingualuit Crater Lake}

Pingualuit Crater Lake $\left(61^{\circ} 17^{\prime} \mathrm{N}, 73^{\circ} 41^{\prime} \mathrm{W}\right.$; $520 \mathrm{~m}$ asl, diameter $3.4 \mathrm{~km}$, cover photo) resulted from a meteoritic impact that occurred ca. 1.4 million years ago. Due to its unique bowl-shaped morphometry (270 $m$ deep, almost perfectly circular), the lake bottom should have escaped glacial erosion. Based on a single punctual seismic survey, the uppermost $8.5 \mathrm{~m}$ of sediments were recovered (overall length of all sediment sections $=11.2 \mathrm{~m}$ ) through the ice at a water depth of $260 \mathrm{~m}$ by an international team in early May 2007 (Fig. 1b). High-resolution physical (CAT-Scan, Multi Sensor Core Logger, diffuse spectral reflectance), geochemical (ITRAX core scanner, carbon and nitrogen contents, $\delta^{13} \mathrm{C}$ of the organic matter), and magnetic (magnetic susceptibility, natural, anhysteretic, isothermal and saturation isothermal remanent magnetizations) analyses were performed. Two main lithofacies were clearly identified by the different measurements, which likely represent successive interglacial-glacial cycles. Most of the sediment consists of light grey silts containing several angular rock fragments, characterized by very low organic carbon content, relatively high density and magnetic susceptibility, and therefore suggesting deposition during 


\section{Full Reference List:}

Angulo, R.J, Lessa, G.C. and de Souza, M.C., 2006: A critical review of mid-to late Holocene sea-level fluctutions on the eastern Brazilian coastline, Quaternary Science Reviews, 25: 486-506.

Bracco, R., Inda, H., del Puerto, L., Castiñeira, C, Sprechmann, P. and García-Rodríguez, F., 2005: Relationships between Holocene sea level variation, trophic development and climate change in Negra Lagoon, southern Uruguay, Journal of Paleolimnology, 33: 252-262.

Bracco, R., García-Rodríguez, F., del Puerto, L., Inda, H. and Castiñeira, C., 2008: Holocene relative sea-level variation inferred from records in the basin of Castillos. In: Structure and function of world shallow lakes, Book of Abstracts, Punta del Este, Uruguay. p. 75.

Cavallotto, J.L., Violante, R.A. and Parker, G., 2004: Sea-level fluctuations during the last 8600 years in the de la Plata River (Argentina), Quaternary International, 114: 155-165.

del Puerto L., 2009: Silicofitolitos como Indicadores Paleoambientales: bases comparativas y reconstrucción paleoclimática a partir del Pleistoceno Tardío en el SE del Uruguay, M.Sc. Thesis PEDECIBA, Facultad de Ciencias, Universidad de la República, Montevideo, 189.

del Puerto, L., Inda, H. and García-Rodríguez, F., 2008: Reconstrucción Paleoambiental para el Holoceno medio y tardío en la cuenca de la Laguna Negra: el aporte de los indicadores biosilíceos. In: Korstanje, A. and Babot, P. (Eds), Matices Interdisciplinarios en Estudios Fitolíticos y de Otros Microfósiles, BAR International Series 1870: 119-129.

del Puerto, L, García-Rodríguez, F., Inda H., Bracco, R., Castiñeira, C., J.B. and Adams, J.B., 2006: Paleolimnological evidence of Holocene paleoclimatic changes in Lake Blanca, southern Uruguay, Journal of Paleolimnology, 36: 151-163.

García-Rodríguez, F., Mazzeo N, Sprechmann P., Metzeltin D., Sosa F., Treutler H.C., Renom M., Scharf B. and Gaucher C., 2002: Paleolimnological assessment of human impacts in Lake Blanca, SE Uruguay, Journal of Paleolimnology, 28: 457-468.

García-Rodríguez, F. et al., 2004: Holocene trophic state changes in relation to sea level variation in Lake Blanca, SE Uruguay, Journal of Paleolimnology, 31: 99-115.

Inda, H., 2009: Paleolimnología de cuerpos de agua someros del sudeste del Uruguay: evolución holocénica e impacto humano, M.Sc. Thesis. PEDECIBA-Biología, Universidad de la República.

Inda, H. et al., 2008: Mid-Holocene palaeoenvironmental reconstruction and recent human impact in Laguna del Diario, SE Uruguay. In: Structure and function of world shallow lakes, Book of Abstracts, Punta del Este, Uruguay, 77.

Isla, F., 1998: Holocene coastal evolution of Buenos Aires, Quaternary of South America and Antarctic Peninsula, 11: 297-321

Martin, L. and Suguio, K., 1992: Variation of coastal dynamics during the last 7000 years recorded in beachridge plains associated with river mouths: example from the Central Brazilian Coast, Palaeogeography, Palaeoclimatology, Palaeoecology, 99: 119-140.

Metzeltin, D., Lange-Bertalot, H. and García-Rodríguez, F., 2005: Diatoms of Uruguay. In: H. Lange-Bertalot (Ed.). Iconographia Diatomologica, Vol. 15. A.R.G. Gantner Verlag, Koeltz Scientific Books, Königstein, 737 pp.

Metzeltin, D. and García Rodríguez, F., 2003: Las Diatomeas Uruguayas, DIRAC Ediciones, Facultad de Ciencias, Montevideo, Uruguay, $208 \mathrm{pp}$.

Piovano, E., Ariztegui, D. and Damatto Moreira, S., 2002: Recent environmental changes in Laguna Mar Chiquita (Central Argentina): A sedimentary model for a highly variable saline lake, Sedimentology, 49: 1371-1384.

Smol, J.P., 1985: The ratio of diatom frustules to chrysophycean statospores: a useful paleolimnological index, Hydrobiologia, 123: 199-208.

Vera, C. et al., 2006: Towards a unified view of the American Monsoon System, Journal of Climate, 19: 49775000 . 